\title{
Desain Model Sistem Ketertelusuran Buah-Buahan di Tingkat Petani Menggunakan Teknologi RFID
}

\author{
Yusuf Priyandari $^{1)}$, Yuniaristanto ${ }^{2)}$, dan Evizal ${ }^{3)}$ \\ ${ }^{1,2)}$ Grup Riset Rekayasa Industri dan Tekno Ekonomi, \\ Teknik Industri, Universitas Sebelas Maret \\ 3) Sekolah Tinggi Teknologi Pelalawan, Riau Indonesia
}

\begin{abstract}
Penelitian menghasilkan sebuah model sistem ketertelurusan (traceability) produk pertanian khususnya buah-buahan di tingkat petani menggunakan teknologi Radio-Frequency Identification (RFID). Model sistem ketertelususan disusun untuk menjamin diterimanya buah-buahan yang aman dan berkualitas oleh konsumen karena konsumen dapat menelusur informasi mengenai buah-buahan secara lengkap mulai dari proses budidaya, panen dan paskapanen yang termasuk di dalamnya rantai dsitribusi.Teknologi RFID dipilih karena banyak digunakan sebagai perangkat penelusuran produk dan telah menjadi salah satu bagian teknologi Near Field Contact (NFC) pada beberapa teknologi smart phone untuk proses pertukaran data.

Penelitian dilakukan dalam tiga tahapan. Tahap pertama adalah melakukan identifikasi rantai pasok buah-buahan yang dikhususkan pada salah satu jenis buah yakni pisang. Kedua, identifikasi bentuk data yang dibutuhkan dan digunakan dalam ketertelusuran buah di tingkat petani. Ketiga, penyusunan model atau desain arsitektur dan infrastruktur ketertelusuran buah-buahan pada tingkat petani. Hasil penelitian ini menggambarkan lebih detail bagaimana ketertelusuran buah-buahan dilakukan menggunakan teknologi RFID dibanding sejumlah artikel yang ada dalam mengkaji umum model ketertelusuran produk pertanian menggunakan teknologi RFID.
\end{abstract}

Keywords: model sistem ketertelusuran buah-buahan, radio frequency identification (RFID), rantai pasok

\section{Pendahuluan}

Ketertelusuran (traceability) produk-produk pertanian semakin tinggi tuntutannya, baik untuk kepentingan dalam negeri maupun untuk kepentingan ekspor/impor (Sudibyo, 2012). Amerika Serikat dan Uni Eropa bahkan telah mensyaratkan labeling negara asal dan sejumlah syarat ketertelusuran lainnya pada sejumlah produk pertanian (Divisi Perdagangan dan Pasar Kantor Regional Asia Pasifik FAO, 2007). Ketertelusuran produk pertanian dimaksudkan untuk menyajikan informasi mengenai seluruh atau sebagian rantai pasok produk-produk pertanian mulai dari pemanenan, pengangkutan, penyimpanan hingga distribusi dan penjualan yang dapat menjamin kualitas dan keamanan produk yang didistribusikan atau dikonsumsi oleh konsumen (Sudibyo, 2012; Divisi Perdagangan dan Pasar - Kantor Regional Asia Pasifik FAO, 2007). Model ketertelusuran dan informasi yang dikelola dalam sistem ketertelusuran dapat dilihat pada Regattieri et al. (2007), Supartono et al. (2011) dan Perdana (2011), dan salah satu informasi penting untuk beberapa negara adalah informasi halal (Divisi Perdagangan dan Pasar Kantor Regional Asia Pasifik FAO, 2007).

Schiefer (2008) dan Sudibyo (2012) mengungkapkan bahwa perlu sebuah sistem berbasiskan teknologi informasi untuk melakukan penelurusan produk pertanian. Regattieri et al., (2007) dan Evizal et al., (2014) secara spesifik mengusulkan penggunaan teknologi Radio Frequency Identification (RFID) untuk ketertelusuran produk pertanian. Penggunaan RFID memungkinkan dilakukan identifikasi objek (produk atau kemasan produk pertanian) secara automatis dari jarak beberapa centimeter hingga beberapa meter dan RFID sendiri telah banyak digunakan dalam bidang penulusuran barang dan rantai pasok (supply chain) (Yuniaristanto, 2010; Srivastava et al., 2009; Priya dan Kumaran, 2011; Foso, 2012; Balint, 2013; Qian, 2014; Qian dan Xie, 2014). Bai et al., (2012),, dan Xie et al., (2013) telah mengkaji gagasan basis

*Correspondance : priyandari@ft.uns.ac.id 
data untuk menyimpan transaksi suatu sistem informasi yang menggunakan teknologi RFID. Namun demikian, sejumlah penelitian seperti Regattieri et al., (2007), Evizal et al., (2014) hanya membahas secara makro (global) dalam desain sistem ketertelusuran produk pertanian. Penelitian-penelitian tersebut belum mengkaji secara detail bagaimana kebutuhan data ketertelusuran dikelola dalam sebuah sistem informasi ketertelusuran produk pertanian menggunakan RFID. Oleh karena itu, penelitian ini mencoba mengkaji desain model sistem ketertelusuran secara lebih rinci dengan mengambil objek kajian pada buah-buahan dan melakukan desain model ketertelusuran yang dimulai pada tingkat petani sebagai titik awal dilakukannya pengumpulan data ketertelusuran.

Rancangan detail sistem ketertelusuran rantai buah-buahan penting untuk segera dikembangkan karena negara-negara pengimpor membutuhkan informasi kualitas dan keamanan produk. Selain itu, di dalam negeri juga terjadi peningkatan kesadaran konsumen dalam memilih produk pertanian. Pemangku kepentingan seperti pemerintah perlu mendukung dikembangkannya sistem ketertelusuran produk pertanian, agar Indonesia tidak hanya menjadi sasaran pasar produk pertanian dari berbagai negara dan di sisi lain produk pertanian Indonesia sulit memasuki negara-negara lain.

Penelitian Sugahara (2007) telah membahas aplikasi ketertelusuran produk pertanian menggunakan RFID dan smart phone. Sistem tersebut diusulkan di Jepang dengan keharusan petani dan entitas rantai pasok terkoneksi internet. Desain tersebut relevan mengingat adopsi teknologi dan ketersediaan internet di Jepang sangat baik. Namun perbedaan budaya petani Indonesia, dan ketersediaan interkoneksi menjadikan desain tersebut perlu dikaji dan dimodifikasi untuk sesuai dengan kebutuhan di Indonesia.

Sistem ketertelusuran rantai pasok produk pertanian adalah suatu sistem kompleks yang melibatkan banyak entitas rantai pasok seperti petani, pengepul distributor, retailer hingga konsumen. Selain banyaknya entitas yang terlibat dalam sistem ini, produk pertanian juga sangat banyak jenisnya, mulai dari kelompok bahan makanan pokok, buah-buahan, sayurmayur, dan berbagai jenis produk pertanian lainnya. Oleh karena itu, penelitian ini difokuskan pada kajian ketertelusuran buah-buahan dengan mengambil studi awal pada buah pisang untuk mendapatkan pola yang tepat dalam pengembangan sistem ketertelusuran rantai pasok produk pertanian. Buah pisang dipilih sebagai sampel karena buah ini merupakan salah satu buah penting Indonesia dan merupakan komoditas ekspor (Hadiwiyono, 2010). Entitas rantai pasok yang dikaji juga dibatasi pada tingkat pertama yaitu petani sebagai produsen buah-buahan. Diharapkan model atau desain awal dari penelitian ini dapat menjadi inisiasi kajian sistem ketertelusuran menggunakan teknologi RFID untuk seluruh produk-produk pertanian dan pada semua entitas rantai pasok dan terbentuknya model komersialisasi sistem ketertelurusan rantai pasok produk pertanian untuk peningkatan ekspor produk pertanian Indonesia ke sejumlah negara yang mensyaratkan adanya ketertelusuran produk pertanian.

\section{Metode Penelitian}

Penelitian dilakukan dalam tiga tahapan. Tahap pertama adalah melakukan identifikasi rantai pasok buah-buahan yang difokuskan pada buah pisang. Buah pisang dipilih karena buah ini merupakan salah satu buah penting Indonesia dan merupakan komoditas ekspor (Hadiwiyono, 2010). Identifikasi rantai pasok buah pisang dilakukan dengan melakukan observasi pada salah satu daerah penghasil buah pisang yaitu Kecamatan Tawangmangu, Kabupaten Karangayar, Propinsi Jawa Tengah. Observasi dilakukan pada satu daerah saja karena entitas yang diamati dalam penelitian ini dibatasi pada petani sebagai produsen sehingga diasumsikan pola distribusi buah pisang pada berbagai daerah dari petani ke entitas rantai pasok berikutnya tidak signifikan berbeda. Studi literatur mengenai rantai pasok buah pisang seperti pada Supartono et al. (2011) juga digunakan sebagai sumber informasi menyusunan pola rantai pasok buah-buahan.

Tahap kedua adalah identifikasi bentuk data yang dibutuhkan dan digunakan dalam ketertelusuran buah di tingkat petani. Sejumlah literatur seperti Regattieri et al. (2007), Divisi Perdagangan dan Pasar - Kantor Regional Asia Pasifik FAO (2007), Yulianingsih, et al. (2010), Broto (2010), Supartono et al. (2011), dan Perdana (2011) digunakan untuk mendapatkan 
bentuk data yang akan dikelola pada sistem ketertelusuran data. Wawancara juga dilakukan pada beberapa petani dan staff Dinas Pertanian Kabupaten Karanganyar. Wawancara dilakukan untuk mengetahui gambaran umum budidaya buah pisang dan tatacara penjualan buah pisang yang dilakukan petani.

Tahap ketiga adalah penyusunan model atau desain arsitektur dan infrastruktur ketertelusuran buah-buahan pada tingkat petani. Tahapan ketiga ini disusun berdasarkan informasi yang diperoleh pada tahap kesatu dan kedua serta menggunakan literatur relevan dalam perancangan sistem informasi. Tahapan ketiga ini menghasilkan skema umum sistem ketertelusuran buah-buahan yang menjelaskan peran entitas yang terlibat. Tahapan ketiga ini juga memaparkan bentuk teknologi RFID yang relevan digunakan untuk mendukung implementasi sistem ketertelusuran buah-buahan. Bagian akhir pada tahapan ini adalah memaparkan cara kerja sistem ketertelusuran buah-buahan menggunakan teknologi RFID dan desain arsitektur perangkat RFID yang digunakan petani. Pembahasan detail prototipe perangkat RFID yang digunakan petani tidak dibahas dalam makalah ini, tetapi akan disajikan dalam tulisan berikutnya.

\section{Hasil dan Pembahasan}

Pisang Tawangmangu merupakan salah satu produk buah-buahan yang sudah popular untuk beberapa pasar di wilayah Jawa Tengah. Pisang yang tumbuh di Tawangmangu lebih besar, tahan lama, tidak cepat busuk dan buahnya terasa manis. Berdasarkan wawancara, jumlah produksi pisang di Kecamatan Tawangmangu lebih sedikit dari jumlah pisang yang beredar di pasaran yang diklaim sebagai pisang Tawangmangu. Sejumlah produk pisang dari luar Tawangmangu sering didistribusikan terlebih dahulu ke area Tawangmangu untuk kemudian didistribusikan ke berbagai pasar. Dengan demikian, sistem ketertelurusan buah menjadi penting untuk menjaga nama pisang Tawangmangu. Beberapa jenis pisang yang dikembangkan di Tawangmangu, antara lain pisang ambon (putih, ijo, dan kuning), pisang biok lokal, pisang raja, pisang bawen (putih dan ijo), dan pisang emas.

\subsection{Rantai pasok buah pisang}

Petani sebagai entitas awal dalam rantai pasok buah memiliki beberapa tingkatan. Tingkatan organisasi petani ini umumnya sama di seluruh wilayah Indonesia menurut staff Dinas Pertanian. Namun demikian, banyak juga petani yang belum terorganisasi secara baik atau sering ditemui organogram petani tidak berjalan efektif seperti yang diharapkan oleh pemerintah. Organisasi petani yang ditemui di wilayah Tawangmangu disajikan pada gambar 1 .

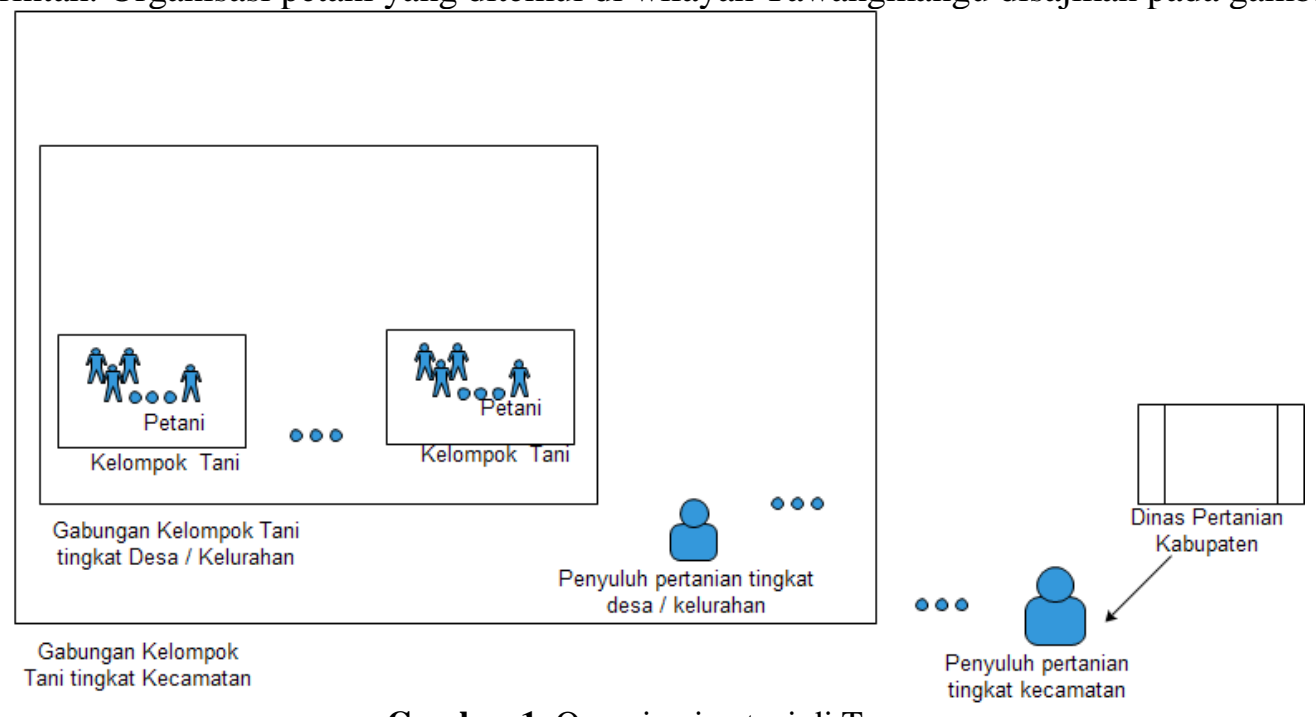

Gambar 1. Organisasi petani di Tawangmangu 
a. Petani

Penjelasan organisasi petani di Tawangmangu sebagai berikut:

Petani yang ada di Kecamatan Tawangmangu biasanya hanya mempunyai lahan yang ditanami untuk satu jenis tanaman saja.

b. Kelompok tani

Gabungan dari beberapa petani disebut kelompok tani. Setiap kelompok tani memliki anggota sekitar 20 petani. Kecamatan Tawangmangu terdapat 91 kelompok tani aktif.

c. Gabungan kelompok tani tingkat desa / kelurahan

Gabungan kelompok tani tingkat desa atau kelurahan digunakan sebagai sarana koordinasi antar kelompok tani dan kegiatan penyuluhan oleh petugas penyuluh tani tingkat kelurahan.

d. Gabungan kelompok tani tingkat kecamatan

Tingkatan ini ditujukan untuk sarana koordinasi pada tingkat kecamatan. Kordinasi umumnya juga melibatkan penyuluh dan staff dari kantor Dinas Pertanian.

Organisasi petani tidak mengambil peran dalam rantai distribusi buah pisang pada khususnya, dan buah-buahan lain pada umumnya. Penjualan buah dilakukan langsung oleh setiap petani kepada pengepul / penebas atau kepada pedagang pasar. Penjualan dan rantai distribusi khusus untuk buah pisang disajikan pada gambar 2. Adapun berdasarkan wawancara dengan petugas dari Dinas Pertanian Kabupaten Karanganyar, proses penjualan dan distribusi buah-buahan lain tidak berbeda dengan pola yang disajikan pada gambar 2. Pola distribusi yang disajikan pada gambar 2 tidak mengakomodir pola distribusi buah pisang dari daerah lain yang masuk terlebih dahulu ke pasar Tawangmangu kemudian dijual ke luar daerah Tawangmangu karena titik fokus observasi untuk melihat bagaimana buah berpindah dari petani ke entitas rantai pasok berikutnya.

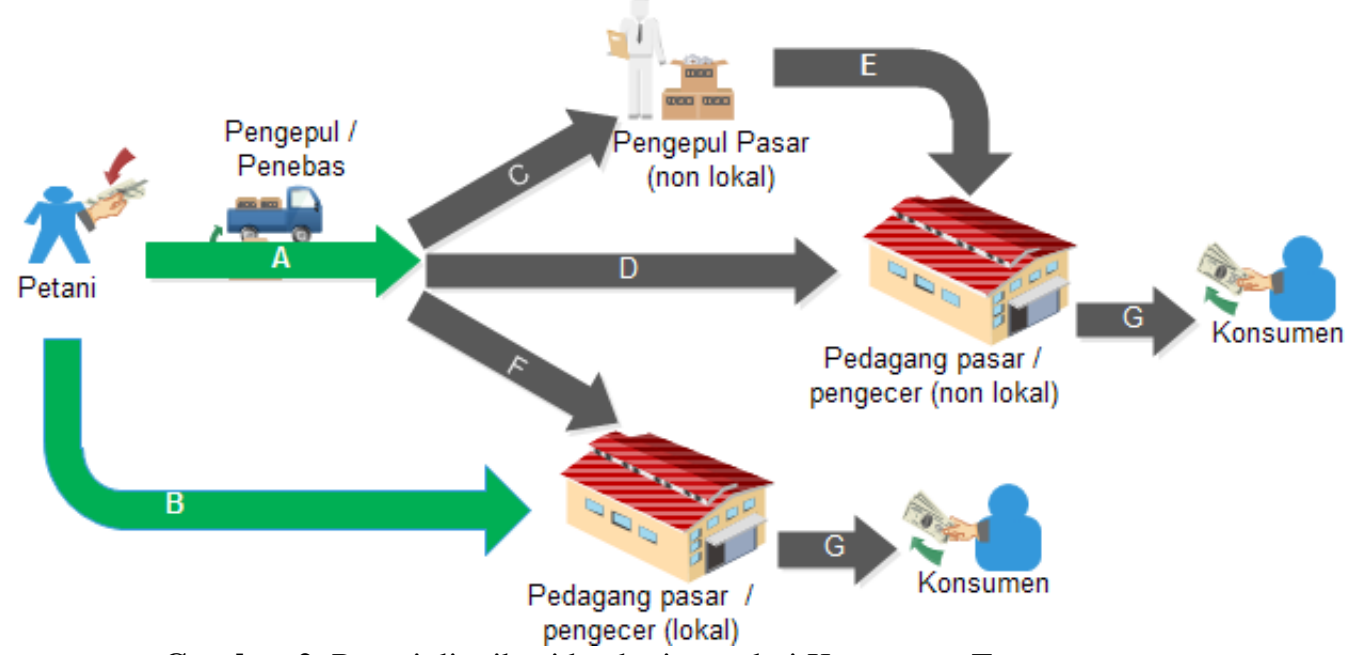

Gambar 2. Rantai distribusi buah pisang dari Kecamatan Tawangmangu

Rantai distribusi buah pisang dijelaskan sebagai berikut:

A. Petani menjual buah pisang melalui pengepul atau penebas. Pengepul adalah pihak yang membeli beberapa pohon/tandan pisang dari petani. Penebas adalah pihak yang membeli semua pohon/tandan pisang yang terdapat di lahan petani. Apabila penjualan pisang dilakukan kepada penebas, maka proses panen sepenuhnya dilakukan oleh pihak penebas. Apabila pisang dijual kepada pengepul, maka proses panen ada dua kemungkinan, yakni dilakukan oleh petani atau bisa juga dilakukan oleh pengepul tergantung kesepakatan penjualan yang dilakukan oleh petani kepada pengepul.

B. Petani menjual buah pisang kepada pedagang pasar (pengecer) di pasar lokal Tawangmangu. Hal ini biasa dilakukan untuk skala produksi yang kecil.

C. Pengepul/penebas menyalurkan buah pisang kepada pengepul pasar di pasar-pasar di luar Tawangmangu, atau 
D. Pengepul/penebas menyalurkan buah pisang kepada pedagang pasar (pengecer) di pasarpasar di luar Tawangmangu.

E. Pengepul pasar (dari luar Tawangmangu) menyalurkan buah pisang kepada pedagang pasar (pengecer) di luar Tawangmangu.

F. Pengepul/penebas menyalurkan buah pisang kepada pedagang pasar (pengecer) lokal Tawangmangu.

G. Pedagang pasar (pengecer) menjual buah pisang kepada konsumen akhir. Konsumen akhir ada dua bentuk, yaitu konsumen perseorangan dan konsumen nonperseorangan seperti rumah sakit, rumah makan, hotel dan lain sebagainya.

\subsection{Bentuk data ketertelusuran buah}

Berdasarkan studi literatur dan observasi, bentuk data ketertelusuran di tingkat petani yang perlu dikelola oleh sistem ketertelurusan disajikan pada tabel 1 .

Tabel 1. Data ketertelusuran di tingkat petani

\begin{tabular}{|c|c|c|}
\hline Kategori & Sub katagori & Item Data \\
\hline \multirow[t]{6}{*}{ Tanaman } & Nama & Nama tanaman \\
\hline & Tampilan & $\begin{array}{l}\text { Ukuran, volume,nisbah diameter panjang / lebar, } \\
\text { kehalusan, kepadatan, keseragaman, warna, kilap, } \\
\text { cacat, patologis, dan sebagainya }\end{array}$ \\
\hline & Tekstur & $\begin{array}{l}\text { Kekokohan, kekerasan, kelembutan, kerenyahan, } \\
\text { sifat berair, terasa bertepung, terasa berpasir, } \\
\text { keliatan, terasa berserat }\end{array}$ \\
\hline & Cita rasa & $\begin{array}{l}\text { Kemanisan, keasaman, kesepetan, kepahitan, } \\
\text { aroma, cita-rasa asing dan bau asing. }\end{array}$ \\
\hline & Nilai gizi & $\begin{array}{l}\text { Karbohidrat (termasuk serat makanan), protein, } \\
\text { lemak,vitamin dan mineral }\end{array}$ \\
\hline & Kelas buah (SNI) & Buah super, Kelas A, Kelas B \\
\hline \multirow[t]{4}{*}{ Panduan Budidaya } & Panduan budidaya & $\begin{array}{l}\text { Organik / nonorganik, jenis pupuk, waktu } \\
\text { pemupukan }\end{array}$ \\
\hline & Panduan panen & Alat panen, umur kematangan buah, \\
\hline & Panduan paskapanen & $\begin{array}{l}\text { Pencucian, curing, degreening, waxing, } \\
\text { penyimpanan }\end{array}$ \\
\hline & Rekomendasi pengangkutan & $\begin{array}{l}\text { Wadah pengangkutan, kendaraan angkut, lama } \\
\text { disitribusi }\end{array}$ \\
\hline \multirow[t]{2}{*}{$\begin{array}{l}\text { Pelaksanaan } \\
\text { Budidaya }\end{array}$} & Cara budidaya & $\begin{array}{l}\text { Organik / nonorganik, waktu pemupukan, jenis } \\
\text { pupuk }\end{array}$ \\
\hline & Lokasi & Lokasi asal buah (desa,, kelompok tani) \\
\hline \multirow[t]{3}{*}{ Panen } & Waktu tanam & Tanggal penanaman, tanggal mulai berbuah \\
\hline & Waktu panen & Tanggal panen \\
\hline & Umur buah & Estimasi umur buah \\
\hline \multirow[t]{2}{*}{ Paskapanen } & Perlakuan & $\begin{array}{l}\text { Pencucian, curing, degreening, waxing, zat aditif } \\
\text { (organik / nonorganik) }\end{array}$ \\
\hline & Distribusi & $\begin{array}{l}\text { Nama lokasi, nama pihak pendistriusi, tanggal jual } \\
\text { beli }\end{array}$ \\
\hline
\end{tabular}

Sumber : (Yulianingsih, et al., 2010; Broto, 2010; Prabawati, 2010; Supartono, et al., 2011; dan observasi )

Data pada kategori tanaman dan panduan budidaya adalah data yang bersifat mandatori setiap jenis buah yang masuk dalam sistem ketertelusuran. Kategori tanaman berisi informasi karakteristik buah yang dapat dijadikan sumber informasi bagi entitas rantai pasok (pengepul hingga konsumen akhir) untuk memastikan bahwa buah yang akan dibeli dan disebutkan oleh penjual memiliki karakteristik yang sama seperti tertera dalam informasi kategori tanaman. 
Dengan demikian calon pembeli tidak keliru atau salah dalam membeli buah. Informasi pada kategori tanaman dan panduan budidaya juga dapat dijadikan sumber informasi bagi petani dalam melakukan budidaya buah-buahan. Data kategori tanaman dan panduan budidaya diinput oleh pemerintah atau pihak penanggungjawab sertifikasi buah.

Data kategori pelaksanaan budidaya, panen dan paskapanen memberikan informasi nyata / sebenarnya mengenai buah yang masuk dalam rantai pasok. Data ini masuk di tingkat petani karena petanilah yang mengetahui jenis buah yang dihasilkan, bagaimana perlakuan budidaya buah, bagaimana melakukan proses panen dan paskapanen. Data yang diinputkan oleh petani inilah yang akan dibaca oleh konsumen akhir melalui sistem ketertelusuran buah. Sebagai contoh, data lokasi yang melekat pada tag RFID buah memudahkan konsumen akhir memastikan sumber atau daerah penghasil buah yang dibeli.

\subsection{Entitas sistema ketertelusuran buah}

Entitas sistem ketertelusuran buah disajikan pada gambar 3. Entitas ketertelusuran buah terdiri dari dinas pertanian, petani, dan pengepul atau penebas. Entitas lain seperti pengepul pasar, pedagang pasar (pengecer), konsumen akhir dan pengelola database ketertelusuran belum dikaji dalam makalah ini.

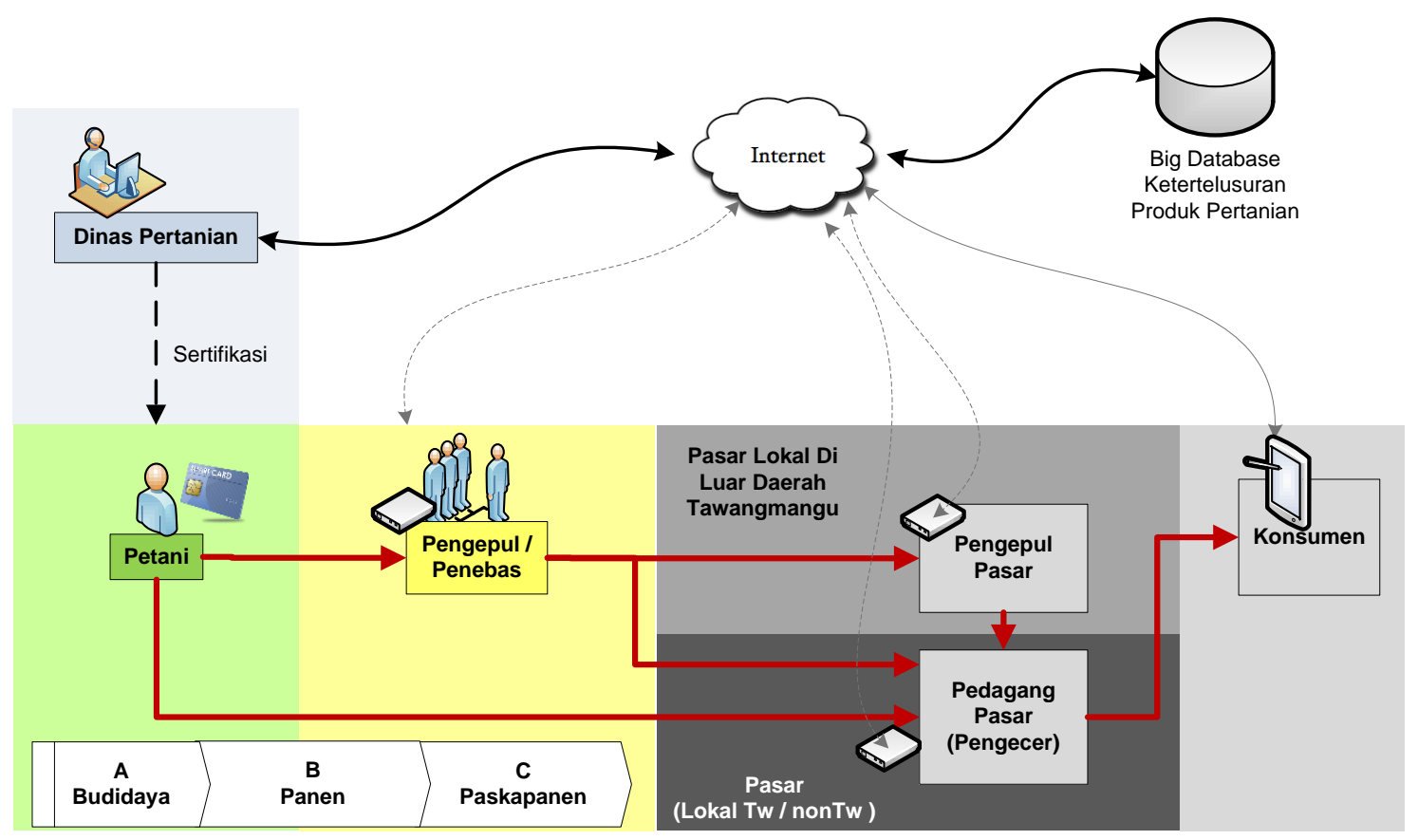

Gambar 3. Entitas ketertelusuran buah di tingkat petani

1. Dinas pertanian.

Dinas pertanian yang dimaksud adalah dinas pertanian tingkat kabupaten. Peran yang dilakukan dinas pertanian adalah:

a. Mengelola data buah ketertelusuran buah.

Data yang dikelola adalah kelompok data "Tanaman" dan "Panduan Budidaya" sebagaimana disajikan pada tabel 1 .

b. Melakukan sertifikasi petani buah.

Sertifikasi petani buah saat ini sudah dilakukan oleh dinas pertanian khususnya untuk petani buah melon. Skema sertifikasi petani buah perlu ditingkatkan dan diperluas untuk berbagai jenis buah sehingga aspek kepercayaan terhadap petani buah meningkat. Sertifikasi ini dapat diparalelkan dengan pemanfaatan database petani buah untuk implementasi teknologi RFID pada sistem ketertelusuran.

2. Petani 
Peran petani sebagai berikut:

a. Mengambil sertifikasi petani buah.

Petani perlu mendapat sertifikasi petani buah sebagai upaya tetap terdapatnya pengawasan kepada para petani dalam aspek penggunaan jenis tanaman buah, tatacara budidaya, penanganan panen dan paskapanen. Data petani tersertifikasi disimpan dalam database ketertelusuran produk pertanian. Data sertifikasi juga disimpan dalam tag RFID yang bisa berupa kartu (smart card) atau tag lain yang relevan untuk menyimpan data sertifikasi. Pada saat dilakukan penjualan buah, tag RFID petani wajib dibaca oleh alat pembaca RFID yang dibawa pengepul/penebas untuk membentuk data ketertelusuran buah bersumber dari petani. Data ketertelusuran kategori "pelaksanaan budidaya" dapat dimasukkan ke dalam tag sebagai bagian dari tindak lanjut sertifikasi.

b. Suplai data ketertelusuran.

Data yang secara berkala perlu disuplai adalah data "panen" sebagaimana tabel 1. Suplai data ke dalam sistem ketertelusuran menggunakan alat yang dibawa oleh pengepul/penebas sehingga petani tidak dibebani oleh kemampuan menggunakan alat RFID.

Data yang disuplai petani bisa juga terlebih dahulu disimpan menggunakan sebuah aplikasi sederhana berbasis Andriod yang kemudian dengan menggunakan teknologi RFID data tersebut dipindahkan ke tag atau alat RFID yang dibawa oleh pengepul/penebas. Detail mekanisme pemberian tag dijelaskan pada bagian lain.

3. Pengepul/Penebas

Peran pengepul/penebas sebagai berikut:

a. Suplai data ketertelurusan.

Data yang disuplai adalah kelompok data "Paskapanen" pada tabel 1.

b. Memberi tag pada buah.

Setiap pengepul/penebas menggunakan sebuah alat berbasis RFID. Alat ini diregistrasi dalam sistem ketertelusuran buah-buahan. Pengepul/penebas bertugas memberi tag RFID pada setiap produk yang dibeli dari petani. Detail mekanisme pemberian tag dijelaskan pada bagian lain.

\subsection{Teknologi RFID yang relevan}

Tipe RFID yang diusulkan adalah High Frequency (HF) RFID yang memiliki frekuensi 13,5 MHz. Beberapa alasan penggunaan HF RFID untuk sistem ketertelusuran buah-buahan sebagai berikut:

a. HF RFID umumnya digunakan untuk tracking pada level satuan (item) produk (Myerson, 2007; Sanghera, 2007 ). Level satuan untuk buah-buahan berbeda-beda. Buah pisang dijual dalam satuan tandan dari petani kepada pengepul/penebas dan dijual dalam satuan sisir dari pengecer kepada konsumen akhir. Buah seperti melon, semangka pepaya menggunakan satu satuan buah. Buah-buahan seperti mangga, apel, dan pir umumnya menggunakan satuan berat (gram atau kilogram) dalam penjualannya. Tag HF RFID dapat harus dapat dipasang pada level satuan penjualan, mulai dari entitas petani hingga pengecer.

b. HF RFID dengan frekuensi 13,5 MHz merupakan salah satu bagian teknologi Near Field Contact (NFC) yang telah melekat beberapa teknologi smart phone untuk proses pertukaran data. Penggunaan HF RFID akan memungkinkan smart phone konsumen akhir untuk mendeteksi data buah yang akan dibeli sekaligus melakukan ketertelusuran data buah.

c. Teknologi NFC telah tertanam pada smartphone Adanya teknologi NFC yang melekat pada smart phone memungkinkan dikembangkan alat berbasis smart phone untuk pembaca dan penulis data dan sekaligus pengirim data ketertelusuran ke database sistem ketertelusuran. Alat berbasis smart phone yang ditunjang dengan aplikasi sederhana diharapkan dapat memenuhi kebutuhan alat di tingkat petani, pengepul/penebas, hingga pengecer.

d. Teknologi HF RFID dengan frekuensi 13,5 MHz relatif murah dibanding UHF RFID. Harga tag HF RFID sekitar US \$0,05 sampai US \$0,2 perunit atau sekitar Rp600 sampai Rp2400 /unit tergantung jenis tag yang digunakan. 
e. Data yang dapat disimpan dalam tag sebesar 768 bytes untuk jenis tag $1 \mathrm{~Kb}$, dan sekitar 4 kalinya untuk jenis tag $4 \mathrm{~Kb}$. Data sebesar 768 bytes sudah sangat cukup untuk menyimpan kode-kode ketertelusuran produk.

f. Bentuk Tag HF RFID yang sangat beragam, mulai dari stiker, gantungan kunci, wristband dan lain sebagainya.

Bentuk tag untuk digunakan pada item buah disesuaikan dengan satuan penjualan atau kemasan yang digunakan oleh buah. Sebagai contoh untuk buah pisang dapat digunakan bentuk wristband karena tag ini dapat dikaitkan atau dikalungkan pada tandan atau sisir buah buah pisang. Bentuk wristband HF RFID disajikan pada gambar 4.
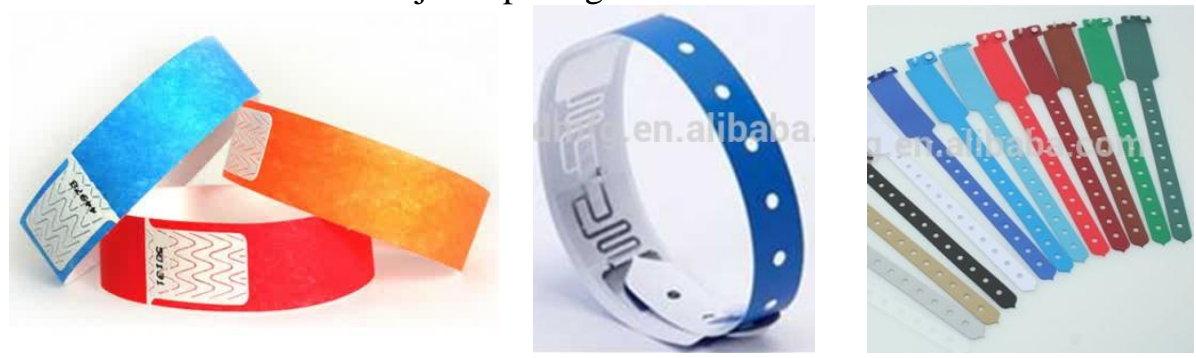

Gambar 4. Usulan tag RFID untuk ketertelusuran buah pisang

\subsection{Skema sistem ketertelusuran}

Skema sistem ketertelusuran pada bagian ini menjelaskan bagaimana data yang disimpan pada database, data pada tag petani, dan data pada tag buah membentuk sistem ketertelusuran buah-buahan. Pertukaran dan / atau penambahan data pada tag petani dan tag buah juga dijelaskan pada bagian ini.

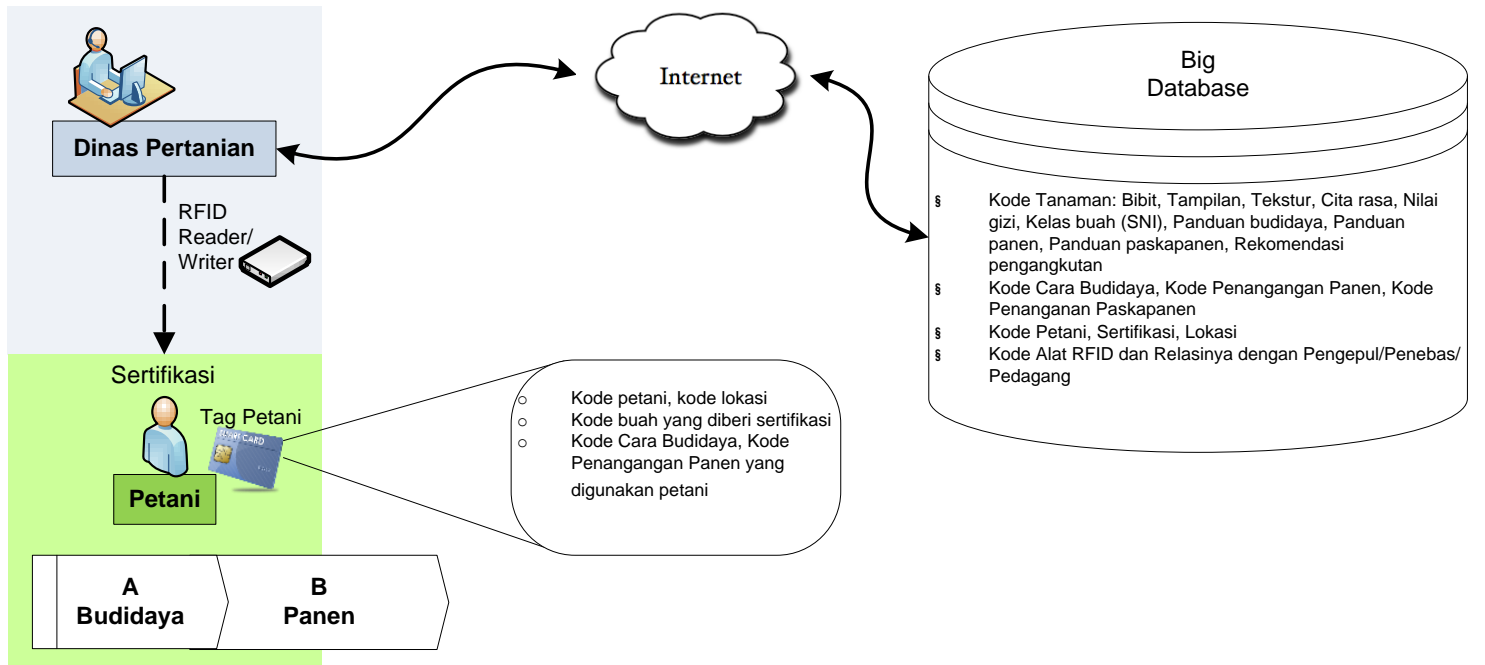

Gambar 5. Skema data pada big database dan tag petani

Gambar 5 menyajikan skema data yang disimpan pada big database dan tag petani. Big database adalah suatu sistem pengelolaan database yang menyimpanan data sistem ketertelusuran buah yang mencakup data kategori tanaman, panduan budidaya, petani tersertifikasi, alat pembaca/penulis RFID, pengepul/penebas, hingga semua entitas rantai pasok yang terlibat. Data tersebut dikelola oleh dinas pertanian atau pemangku kepentingan lain yang ditunjuk pemerintah untuk memastikan data yang masuk dalam sistem ketertelusuran adalah data yang benar. Sebagaimana sebuah database yang baik dibangun, setiap tabel data memiliki kode kunci yang unik untuk memudahkan pencarian suatu record data sehingga kode kunci inilah yang berelasi dengan tabel lain dan ditransfer ke dalam tag petani atau tag buah.

Dalam skema ini, petani tidak dibebani dengan kebutuhan koneksi internet karena petani diberikan sebuah tag RFID (bisa berupa kartu atau bentuk lain) sebagai pengganti 
sertifikat petani buah. Tag RFID petani ini menyimpan data jenis buah yang ditanam beserta tata cara budidaya dan panen yang harus ditaati petani. Secara berkala pengawas pertanian atau penyuluh pertanian melakukan pengawasan atau evaluasi terhadap tata cara budidaya dan panen petani sebagai kelanjutan sertifikasi dan memastikan bahwa petani masih berhak memegang tag RFID (pengganti sertifikat). Apabila terdapat penambahan jenis buah atau perubahan tatacara budidaya dan panen yang akan dilakukan petani, maka dinas pertanian melakukan perubahan data pada tag petani menggunakan alat penulis data RFID (RFID writer) yang dimiliki oleh dinas pertanian. Petani dapat membaca data tag RFID yang dimiliki secara detail menggunakan aplikasi berbasis smart phone. Pada kasus ini, aplikasi memerlukan koneksi data untuk melakukan sinkronisasi antara data yang tersimpan dalam tag RFID petani (yang berupa kode) dengan detail data yang perlu dibaca yang diambil dari database sistem ketertelusuran. Sinkronisasi dilakukan hanya apabila aplikasi smart phone baru pertama kali digunakan, atau ketiga kode-kode atau data dalam tag RFID petani mengalami perubahan.

Bagian selanjutnya adalah bentuk umum data pada tag buah seperti disajikan pada gambar 6. Pada bagian ini tag buah yang digunakan disebut sebagai "Tag Tandan" karena menggunakan satuan tandan untuk studi kasus buah pisang. Analogi yang sama dapat digunakan untuk berbagai buah lain dimana satuan yang digunakan bisa berupa peti, kardus, palet dan lain sebagainya.

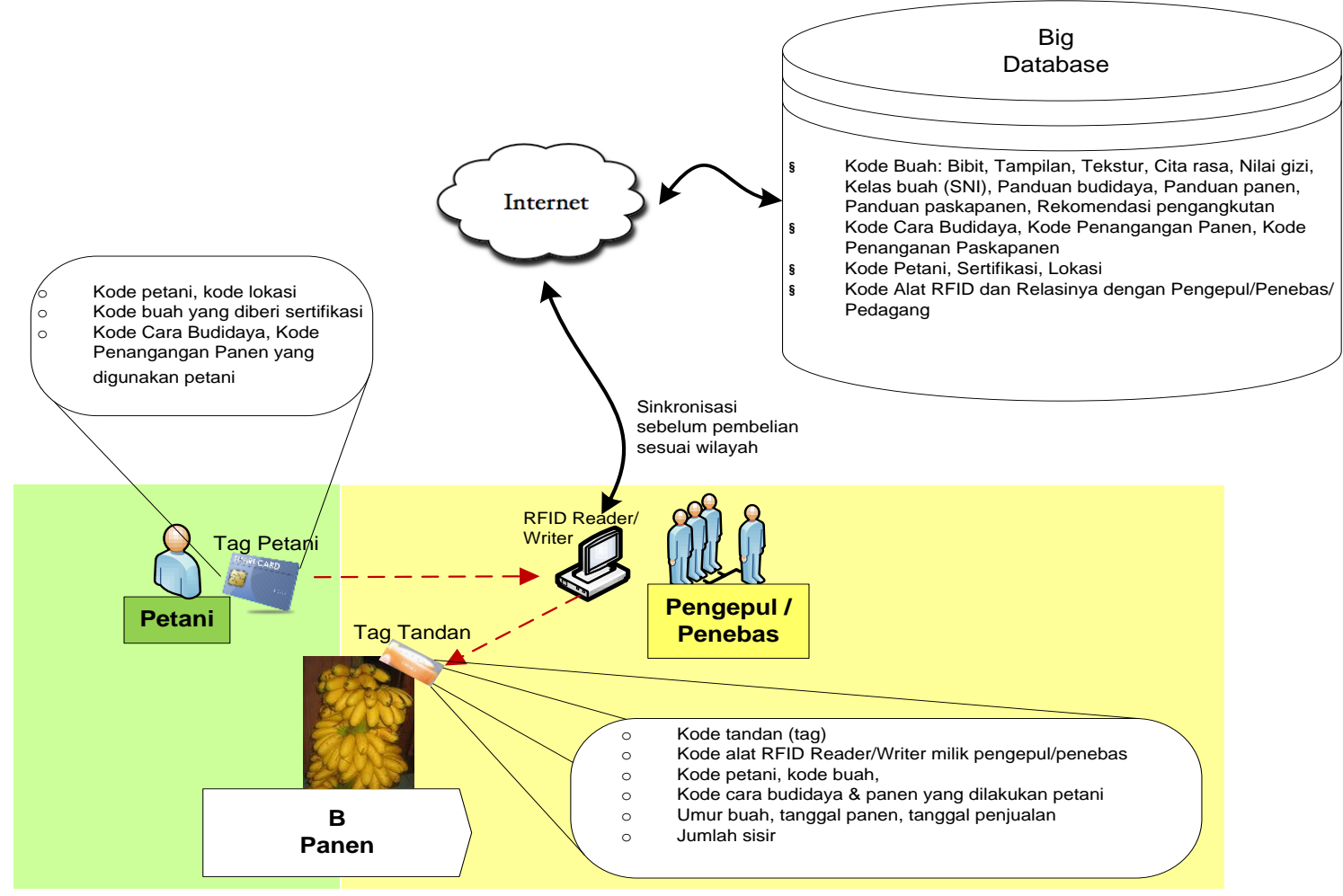

Gambar 6. Skema data pada tag tandan

Setiap pengepul/penebas memiliki alat RFID yang dirancang khusus untuk menangani sistem ketertelusuran buah. Alat RFID ini terdaftar (registered) pada big database sistem ketertelusuran buah. Alat RFID ini memiliki database lokal untuk menyimpan sejumlah data yang sama dengan big database, hanya saja jumlah atau besaran data yang disimpan dibatasi sesuai dengan wilayah kerja pengepul/penebas. Contoh data yang disimpan pada alat RFID antara lain kode buah, bibit, kelas buah (SNI), kode cara budidaya, kode penangangan panen, kode penanganan paskapanen, kode petani, lokasi, kode alat RFID pengepul/penebas.

Data yang tersimpan dalam alat RFID tersebut diperoleh melalui proses singkronisasi. Sinkronisasi data pada alat RFID pengepul/penebas dilakukan beberapa kali. Pertama kali diperlukan singkronisasi data pada saat alat pertama kali digunakan. Sinkronisasi dilakukan juga ketika pengepul/penebas akan melakukan pembelian pada wilayah yang datanya belum ada 
pada alat. Sinkronisasi dilakukan ketika diketahui tag petani belum ada dalam data alat RFID pengepul/penebas. Sinkronisasi diperlukan juga ketika diketahui petani telah melakukan update data pada tag yang dimiliki. Alat RFID pengepul/penebas dengan demikian memerlukan fasilitas interkoneksi dengan big database.

Proses pembentukan data ketertelusuran mulai terjadi pada saat pembelian dilakukan. Pengepul/penebas menggunakan alat RFID untuk membaca data pada tag petani dan menuliskan data pada tag tandan. Skema data yang disimpan pada tag tandan disajikan pada gambar 6 yang antara lain berisi data kode tag, kode alat RFID, kode petani, kode buah, umur buah, tanggal panen, tanggal pembelian dan lain sebagainya. Data yang disimpan dalam tag hanya berupa kode dan idealnya data tersebut terenkripsi. Alat RFID yang dibawa oleh pengepul/penebas didesain portable dan dilengkapi mini monitor (touch screen atau ada tambahan keyboard). Tanggal pembelian diset atotmatis pada saat dilakukan tagging pada tag tandan. Jumlah sisir perlu dituliskan dalam tag tandan karena ini menjadi mekanisme mengontrol ketertelusuran buah pada saat dilakukan pemecahan tandan pisang menjadi satuan sisir oleh pengecer.

Untuk memastikan bahwa buah yang dibeli adalah jenis buah tertentu (misal pisang emas tawangmangu) sebagaimana dikatakan oleh petani, maka alat RFID yang dimiliki pengepul harus membaca data pada tag petani. Hasil pembacaan tersebut harus menunjukkan informasi bahwa petani memang tersertifikasi membudidayakan buah yang dimaksud. Hal inilah yang menjadi sebab diperlukannya sinkronisasi data pada alat RFID pengepul/penebas dengan data pada sistem ketertelusuran (big database). Adapun untuk memastikan tata cara budidaya buah yang dilakukan petani sesuai dengan standar budidaya, sepenuhnya tergantung pada intensitas pengawasan yang dilakukan oleh penyuluh pertanian.

Fokus makalah ini pada entitas petani. Namun demikian perlu dijelaskan bagaimana skema data yang tersimpan dalam tag satuan besar (misal tandan pisang) dipecah dalam satuan yang lebih kecil (misal satuan sisir). Pemecahan satuan besar ke satuan kecil harus tetap menjaga integritas data ketertelusuran buah hingga sampai ke konsumen akhir. Secara prinsip apabila terjadi pemecahan buah ke satuan yang lebih kecil maka setiap satuan baru teraebut harus dipasang tag baru. Tag baru tersebut menyimpan kode tertentu yang dapat memberikan informasi ketertelusuran. Kode tertentu tersebut dapat dianalogikan seperti kode genetik atau DNA (Deoxyribonucleic acid) pada makhluk hidup yang dapat menelusur keturunan.

Gambar 7 menyajikan skema data pada tag satuan terkecil. Data dari tag satuan besar dipindahkan ke dalam tag baru yang mewakili buah satuan kecil menggunakan alat RFID yang dipegang oleh entitas rantai pasok. Beberapa data ditambahkan dalam tag baru. Contoh data yang berasal dari tag sebelumnya antara lain umur buah, tanggal panen, lokasi asal buah, dan kode buah. Data baru yang ditambahkan ke dalam tag antara lain kode alat RFID pembeli, kode pemasok dan tanggal beli. Kode yang tersimpan dalam tag akan digunakan konsumen untuk melakukan ketertelusuran data buah.

Konsumen menggunakan aplikasi berbasis smart phone yang memiliki teknologi NFC untuk dapat membaca data yang tersimpan dalam tag buah yang akan mereka beli. Apabila konsumen bermaksud melihat detail data ketertelurusan buah, konsumen memerlukan koneksi internet untuk menganbil data pada big database sistem ketertelusuran. Secara prinsip, informasi minimal mengenai kuantitas dan kualitas buah seperti tanggal panen, nama buah, sumber buah dan kategori kualitas buah harua dapat diketahui konsumen hanya dengan menempelkan alat pembaca tag kepada tag buah tanpa harus menggunakan koneksi internet. Alat pembaca bisa berupa smart phone konsumen yang dilengkapi NFC dan aplikasi atau alat pembaca tag yang tersedia pada pengecer. 


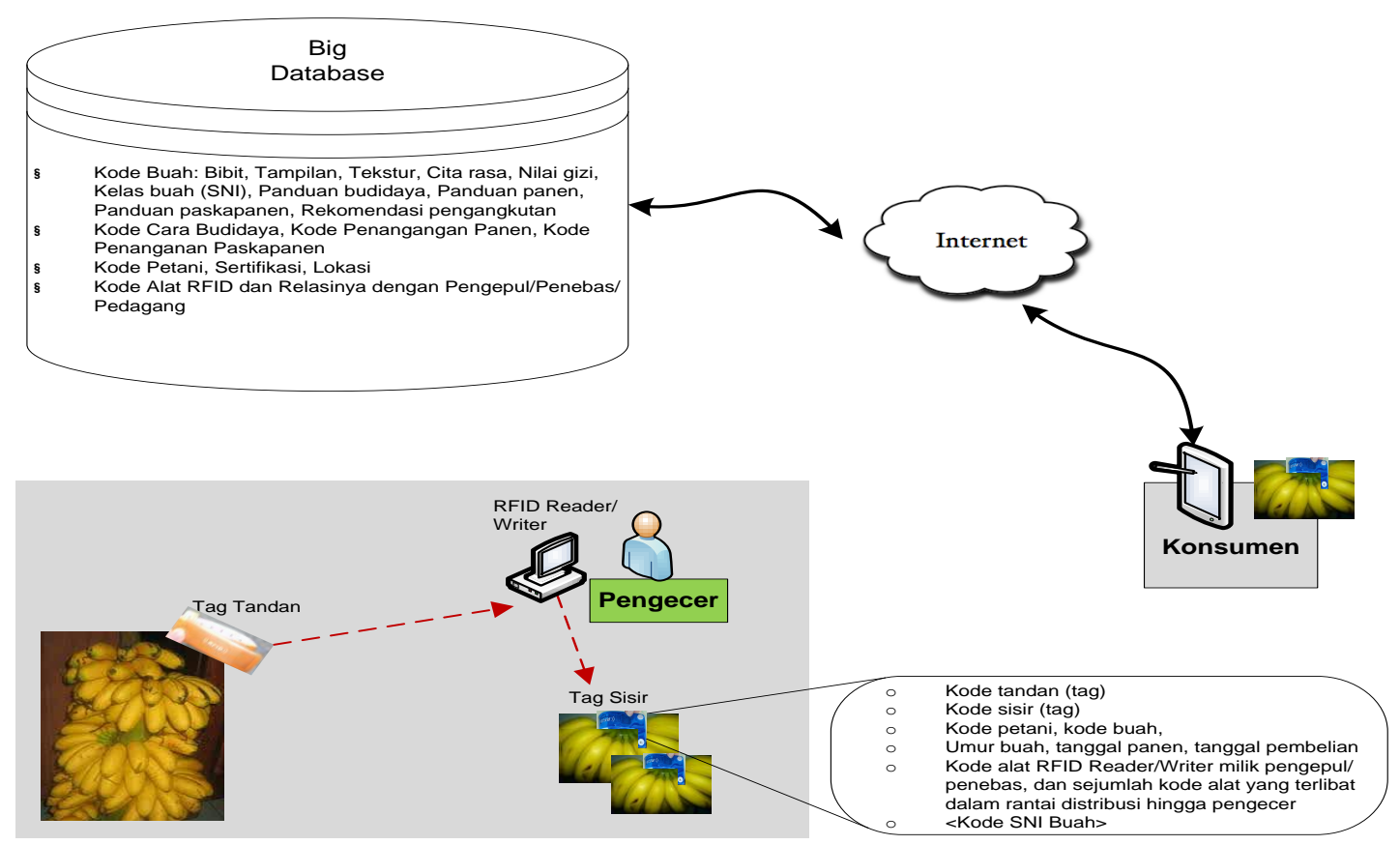

Gambar 7. Skema data pada tag satuan kecil

\section{Kesimpulan dan Saran}

Makalah ini telah menginisiasi suatu bentuk model sistem ketertelusuran buah-buahan menggunakan teknologi RFID. Makalah ini memberikan informasi spesifik rantai pasok buah pisang. Diasumsikan beberapa jenis buah lainnya memiliki rantai pasok yang tidak jauh berbeda. Namun demikian, perlu dilakukan pemetaan terhadap seluruh pola rantai pasok produk-produk pertanian untuk dapat menyusun suatu sistem ketertelusuran produk pertanian di Indonesia.

Makalah ini juga telah memaparkan bentuk data yang dibutuhkan untuk sistem ketertelusuran. Secara umum bentuk data yang disajikan dalam makalah ini lebih rinci dari sejumlah penelitian. Namun demikian, untuk menyusun sebuah sistem informasi ketertelusuran buah-buahan ataupun lebih jauh produk pertanian di Indonesia, maka perlu dilakukan analisi lebih dalam dan mempertimbangkan rambu-rambu penyusunan sebuah database berskala besar. Data yang yang digunakan juga perlu dikaji relasi satu bagian dengan bagian lainnya atau menggunakan metode khusus mengingat beberapa penelitian telah secara khusus membahas model database untuk sistem ketertelusuran menggunakan RFID (Bai, et al., 2012; Xie, et al., 2013).

Cara kerja ketertelusuran, khususnya bagaimana data yang bersumber dari petani mengenai jenis buah, cara budidaya, informasi panen dan paska panen dapat berpindah menggunakan tag RFID telah dipaparkan secara ringkas. Banyak aspek lain seperti bagaimana bentuk algoritma pengkodean data ketertelusuran sehingga setiap entitas dalam rantai pasok hingga konsumen akhir dapat mendapatkan informasi buah-buahan masih perlu dikembangkan. Aspek penting yang belum dibahas dalam makalah ini adalah bagaimana mengubah budaya petani buah dalam kerangka adopsi teknologi.

\section{Daftar Pusaka}

Bai, K., Li, S. \& Liu, T., 2012. A Novel Method for Modelling RFID Data. Journal of Software, Vol. 7(4), pp. 835-843.

Balint, A. O., 2013. An Inquiry Into The Characteristics, Applicability, and Prerequisites RadioFrequency Identification (RFID) Solutions in Transport Network Logistics. Hyperion Economic Journal, Vol. 3(1), pp. 56-64. 
Broto, W., 2010. Prospek Pengembangan Buah Segar untuk Eskpor. In: W. Broto, ed. Teknologi Penanganan Pascapanen Buah untuk Pasar. Jakarta: Badan Penelitian dan Pengembangan Pertanian, Kementerian Pertanian Republik Indonesia, pp. 1 - 26.

Divisi Perdagangan dan Pasar - Kantor Regional Asia Pasifik FAO, 2007. Buku Petunjuk Praktis Bagi Produsen dan Eksportir dari Asia: Peraturan, Standar dan Sertifikasi untuk Ekspor Produk Pertanian. Jakarta: Kantor Regional FAO Untuk Wilayah Asia dan Pasifik.

Evizal, et al., 2014. Food Traceability and Security in Supply Chain Using RFID Technology. Yogyakarta, International Conference on Electrical Engineering, Computer Science and Informatics (EECSI).

Foso, W. S., 2012. Achieving Supply Chain Integration using RFID Technology: the Case of Emerging Intelligent B-to-B e-Commerce Processes in a Living Laboratory. Business Process Management Journal, Volume 18 (1), pp. 58 - 81.

Hadiwiyono, 2010. Insidens Penyakit Layu Bakteri Darah dan Layu Fusarium Pisang di Sambung Macan Sragen dan Tawangmangu Karanganyar. Agrosains, Vol. 12(1), pp. 1923.

Myerson, J. M., 2007. RFID in The Supply Chain, A Guide to Selection and Implementation. New York: Auerbach Publications.

Perdana, Y. R., 2011. Pengembangan Model Tracking dan Tracing dalam Distribusi Komoditi Pertanian. Jurnal Ilmiah Teknik Industri, Vol. 10(1), pp. 1 - 6.

Prabawati, S., 2010. Transportasi, Distribusi dan Ritel. In: W. Broto, ed. Teknologi Penanganan Pascapanen Buah untuk Pasar. Jakarta: Badan Penelitian dan Pengembangan Pertanian, Kementerian Pertanian Republik Indonesia, pp. 69 - 86.

Priya, P. M., Sangeetha, B. \& Kumaran, V. V., 2011. Securing Supply Chain Mangement System Using RFID. International Journal of Computer Science and Technology, Vol. 2(2), pp. 52-57.

Qian, J., Liu, Z. \& Xie, X., 2014. Design and Application of RFID Technology in Container Port. Scientific Journal of Information Engineering, Vol. 4(7), pp. 26-37.

Regattieri, A., Gamberi, M. \& Manzini, R., 2007. Traceability of Food Products: General Framework and Experimental Evidence. Journal of Food and Engineering, Volume Vol. 81, pp. 347-356.

Sanghera, P. et al., 2007. How to Cheat at Deploying and Securing RFID. Burlington: Syngress Publishing Inc.

Schiefer, G., 2008. Tracking and Tracing - A Challenge for System Organozatioon and IT. Journal of Information Technology in Agriculture, Volume Vol. 3, pp. 19 - 25.

Srivastava, S. C., Mathur, S. S. \& Teo, T. S., 2009. Competing technology options and stakeholder interests for tracking freight railcars in Indian Railways. Journal of Information Technology, Volume 24 (4), pp. 392 - 400.

Sudibyo, A., 2012. Sistem Ketertelusuran pada Industri Pangan dan Produk Hasil Pertanian. Warta Industri Hasil Pertanian, Vol. 29(2), pp. 43-62.

Sugahara, Koji. 2007. Traceability System For Agricultural Products Based On Rfid And Mobile Technology. National Agriculture Research Center. pp. 156-162

Supartono, W., Soemardjito, J. \& Indarto, E., 2011. Pengembangan Model Tracking and Tracing Dalam Proses Distribusi untuk Mendukung Kualitas Produk Pertanian. Surabaya, Seminar Nasional Fakultas Pertanian Universitsa Trunojoyo Madura.

Xie, D., Tang, S., Xiao, J., Wang, H., dan Wang, J. 2013. An Extensible Model for Uncertain RFID Data in Supply Chain. Information Technology Journal, Vol. 12(21), pp. 6044 6049.

Yulianingsih, Amiarsi, D., Thahir, R. \& Broto, W., 2010. Mutu Buah dan Faktor-Faktor yang Mempengaruhinya. In: W. Broto, ed. Teknologi Penanganan Pascapanen Buah untuk Pasar. Jakarta: Badan Penelitian dan Pengembangan Pertanian, Kementerian Pertanian Republik Indonesia, pp. 27 - 46.

Yuniaristanto, 2010. Perancangan Prototipe Sistem Perparkiran di Universitas Sebelas Maret dengan Menggunakan Teknologi RFID. PERFORMA, Vol. 9 No. 1. 